Tomasz Różański

ORCID: 0000-0003-3396-0916

Uniwersytet Mikołaja Kopernika w Toruniu

\title{
Czas wolny ludzi starszych w świetle teorii aktywności
}

\author{
The Leisure Time of Older People in Light of \\ Activity Theory
}

\begin{abstract}
ABSTRAKT
Celem niniejszego artykułu jest ukazanie problemu czasu wolnego ludzi starszych w perspektywie teorii aktywności. Punktem wyjścia podjętych rozważań było wyjaśnienie pojęć „starość” i „starzenie się". W dalszej kolejności przedstawiono ważniejsze zagadnienia dotyczq̨ce akływności człowieka w okresie późnej dorosłości oraz zaprezentowano główne założenia teorii akływności. Następnie określono pojęcie czasu wolnego, omówiono cechy aktywności wolnoczasowej, a także wskazano na funkcje czasu wolnego. Zwrócono również uwagę na strukturę budżetu czasu seniorów oraz dominujące wśród nich typy aktywności wolnoczasowej. W następnej kolejności przedstawiono problem czasu wolnego ludzi starych w kontekście teorii aktywności, zwracajqc szczególnq uwagę na zagadnienia dotyczqce aktywizacji seniorów.
\end{abstract}

\section{ABSTRACT}

The purpose of this article is to show the problem of the leisure time of older people from the perspective of activity theory. The starting point for these considerations was to clarify the concepts of "old age"
SLOWA KLUCZOWE aktywizacja, aktywność, czas wolny, człowiek starszy, teoria aktywności

\section{KEYWORDS}

activation, activity, leisure time, elderly man, activity theory

SPI Vol. 23, 2020/1

ISSN 2450-5358

e-ISSN 2450-5366 DOI: 10.12775/SPI.2020.1.007

Nadesłano: 26.11.2019 Zaakceptowano: 8.04.2020 Miscellanea 
and "aging". Next, the most important issues of human activity in late adulthood were presented, and the main assumptions of activity theory were described. Then, the concept of leisure time was defined, the features of leisure time activity were discussed, and the functions of leisure time were indicated. Attention was also paid to the structure of the time budget of seniors and the types of leisure time activity dominating among them. Also the problem of leisure time of old people in the context of activity theory was presented, with special attention paid to the issues of activation of seniors.

Wstęp

Aktywność stanowi warunek konieczny satysfakcjonującego życia bez względu na wiek człowieka (Miszczak 2010: 27). Od niej zależy zaspokojenie wszelkich jego potrzeb. Brak aktywności może prowadzić do utraty akceptacji ze strony innych ludzi, samotności (Dzięgielewska 2006: 161-162), a nawet do wykluczenia społecznego. Istotna jest więc „umiejętność życia aktywnego, świadomego, intencjonalnego, pozytywnego, wartościowego, tworzenie i realizowanie własnej koncepcji życia także w wieku podeszłym" (Pikuła 2011: 110). Prowadzone od kilkudziesięciu lat badania i analizy wskazują, że codzienna aktywność ludzi starszych w Polsce skupia się przede wszystkim na sprawach domowo-rodzinnych (zob. Brzezińska 2011; Trafiałek 2013; Zrałek 2014; Różański 2016). Dotyczy to również ich aktywności wolnoczasowej. Różne mogą być przyczyny tego stanu rzeczy, np. problemy związane ze zdrowiem, brak wiary we własne możliwości, obawa przed krytyką ze strony innych ludzi (Trafiałek 2013: 199).

Postęp techniczny i społeczno-ekonomiczny oraz rozwój medycyny przyczyniły się do wzrostu ilości czasu wolnego, który nie symbolizuje już wyłącznie warstw uprzywilejowanych. Czas wolny stał się istotnym składnikiem jakości życia (Denek 2011: 89-90). Od jego rozmiarów oraz sposobów spożytkowania w dużej mierze „zależy jakość wykonywanej pracy, kształtowania i doskonalenia zawodowego, codziennego samopoczucia i zdrowia” (Denek 2011: 90). Czas wolny spełnia zatem wiele ważnych funkcji w życiu jednostki, również osoby starszej. Uczestnictwo człowieka starego w czasie wolnym może jednak zależeć od różnych czynników, które kształtują jego sytuację 
życiową. W obliczu procesu starzenia się polskiego społeczeństwa problem ten nabiera szczególnego znaczenia. Pociąga za sobą potrzebę realizacji systematycznych badań naukowych oraz podejmowania zróżnicowanych działań, m.in.w dziedzinie edukacji, profilaktyki czy pomocy społecznej.

Celem niniejszego artykułu jest przedstawienie problemu czasu wolnego ludzi starszych w kontekście teorii aktywności, ze szczególnym zwróceniem uwagi na rolę aktywizacji seniorów.

\section{Aktywność w okresie późnej dorosłości}

Starością człowieka, określaną też m.in. jako późna dorosłość (zob. Steuden 2011), zajmują się przedstawiciele różnych dyscyplin naukowych, np. socjologii, psychologii, pedagogiki (Wawrzyniak 2017a: 42).W różnoraki sposób definiują to pojęcie. Według Elżbiety Trafiałek starość stanowi naturalny okres życia, który następuje po młodości i dojrzałości. Jest ona zwieńczeniem dynamicznego procesu starzenia się (Trafiałek 2006: 69). Starość wiąże się

[...] ze spadkiem wydolności organizmu, utratą mobilności, osłabieniem sił immunologicznych (starość biologiczna, fizjologiczna), ograniczeniem zdolności przystosowywania się do wszelkich zmian, a w kontekście socjoekonomicznym - nierzadko też z pauperyzacją, samotnością (starość psychiczna), koniecznością korzystania z pomocy innych (starość ekonomiczna) i funkcjonowaniem na marginesie życia społecznego (starość społeczna) (Trafiałek 2006: 69).

Starzenie się oznacza natomiast „naturalne, przebiegające w różnym stopniu i tempie zmiany w organizmie człowieka, zmniejszenie intensywności procesów życiowych. Jest to proces ciągły i nieodwracalny" (Pikuła 2013: 23). Starość jako faza życia ludzkiego powinna być analizowana $\mathrm{w}$ powiązaniu $\mathrm{z}$ procesem starzenia się oraz jego następstwami (Szarota 2004: 24).

Za początek późnej dorosłości uznaje się zazwyczaj 60. bądź 65. rok życia. Starość nie jest jednak jednolitym etapem życia człowieka, gdyż jego sprawność fizyczna i psychiczna zmienia się wraz $\mathrm{z}$ upływem lat. $Z$ tego powodu późną dorosłość dzieli się na krótsze etapy (Pędich 2002: 917). Zgodnie z podziałem zaproponowanym przez Światową Organizację Zdrowia (WHO), w jej obrębie wyróżnia się trzy podokresy: wczesną starość - wiek starzenia się 
(60-74 lata), starość pośrednią - wiek starczy (75-89 lat) i późną starość - długowieczność (90 lat i więcej) (Błachnio 2019: 26).

Jak zauważa Zofia Szarota: „W wymiarze społecznym starość powoduje zmianę dotychczas pełnionych ról społecznych, dotychczasowej pozycji społecznej oraz postaw społeczeństwa wobec osób starszych" (Szarota 2010: 39). Jednym z głównych zadań rozwojowych okresu starości jest podjęcie nowych ról i zajęć, które wiążą się z przejściem na emeryturę (Leszczyńska-Rejchert 2016: 27). Zaprzestanie pracy zawodowej prowadzi do istotnych zmian w obrębie struktury aktywności człowieka, dochodzi bowiem do eliminacji (bądź znacznego ograniczenia) jednej z zasadniczych ról, jaką pełnił on w trakcie swojego życia (w konsekwencji przeobrażeniom podlegają też inne pełnione role). Przejście na emeryturę wymaga zatem adaptacji do tych zmian, przystosowania się do nowej sytuacji społecznej (Synak 1987: 105). Do czynników, które ułatwiają odnalezienie się w nowej roli (emeryta), należy zaliczyć m.in.: „możliwość realizacji wcześniej poczynionych planów, oddanie się zaniechanej pasji, hobby, podróże, odwiedziny przyjaciól, rodziny, zajęcie się działką, poszerzenie zakresu obowiązków domowych, możliwość wykonywania konkretnego zajęcia lub kontynuowanie pracy w zmienionej formie" (Wawrzyniak 2017a: 58). Przystosowanie się to jest trudniejsze w sytuacji, gdy człowiek w okresie aktywności zawodowej nie przejawiał i nie rozwijał zainteresowań pozazawodowych, nie podejmował innych rodzajów aktywności (Wawrzyniak 2017a: 58). Stąd gerontolodzy często podkreślają potrzebę prowadzenia aktywnego życia, zarówno przed, jak i po przejściu na emeryturę.

Aktywność najogólniej oznacza zdolność do działania, energię, która daje szansę na utrzymywanie kontaktów i porozumiewanie się $\mathrm{z}$ innymi osobami, co jest szczególnie ważne w przypadku ludzi starszych (Kaczmarczyk, Trafiałek 2007: 116). Aktywność seniorów jest często ujmowana w sposób szeroki, jako czynny udział w życiu społecznym, kulturalnym czy intelektualnym (Miszczak 2010: 27). Liczne klasyfikacje uwzględniają też inne rodzaje (formy) aktywności osób w wieku senioralnym. Aleksander Kamiński wskazuje na dwa główne rodzaje aktywności seniorów: podejmowanie pracy cenionej i użytecznej (np. praca będąca kontynuacją zatrudnienia zawodowego, praca zarobkowa w innym zawodzie, aktywność wewnątrzrodzinna, działalność społeczna) oraz rozwijanie własnych zainteresowań 
(np. aktywność fizyczna, klubowa, artystyczna, umysłowa) (Kamiński 1986: 115-117). Inny podział obejmuje następujące rodzaje aktywności: domowo-rodzinną, kulturalną, zawodową, społeczną, edukacyjną, religijną i rekreacyjną (Chabior 2011: 68-69). Podejmowana przez osoby starsze aktywność może spełniać wiele ważnych funkcji w ich życiu. Wymienia się wśród nich m.in.: funkcję adaptacyjną, integracyjną, kompensacyjną, kształcącą, rekreacyjno-rozrywkową (Dzięgielewska 2006: 164).

Zgodnie z założeniami teorii aktywności - jednej z kluczowych teorii wyjaśniających prawidłowości procesu starzenia się człowieka (Wawrzyniak 2017b: 27) - osoby, które zachowują aktywność w okresie późnej dorosłości, wykazują wyższy stopień satysfakcji z własnego życia (Halicki 2006: 262). Co więcej, sposób, w jaki postrzegają siebie seniorzy, zależy „od roli, jaką pełnią, bądź od działań, w które są zaangażowani. Osoby starsze, w celu utrzymania pozytywnego obrazu samego siebie, muszą zastąpić nowymi rolami te, które utraciły wraz z procesem starzenia się. W ten sposób dobre samopoczucie $w$ wieku starszym jest rezultatem wzrastającej aktywności w nowo zdobytych rolach" (Halicki 2006: 262). Teoria aktywności jest uzasadnieniem dla założenia, jakie leży u podstaw rozmaitych programów interwencyjnych na rzecz seniorów - aktywność w okresie późnej dorosłości jest korzystna i prowadzi do wzrostu satysfakcji życiowej (Halicki 2006: 262). Jak wynika z badań gerontologicznych, „osoby, które mimo podeszłego wieku prowadzą aktywny tryb życia, charakteryzują się lepszą kondycją psychiczną i żyją dłużej [...], lepiej znoszą porażki, w mniejszym stopniu są narażone na poczucie bezradności i osamotnienia” (Steuden 2011: 90).

Aktywność stanowi istotną potrzebę psychiczną i społeczną w każdym okresie ludzkiego życia (Szatur-Jaworska 2006a: 20). W fazie starości „człowiek [...] powinien podejmować aktywność zgodnie z własnymi potrzebami i możliwościami, a także oczekiwaniami i staraniami otoczenia (aktywizacja), a pozostawanie czynnym jak najdłużej jest zjawiskiem [...] koniecznym do osiagnięcia zadowolenia" (Chabior 2017a: 66). 


\section{Problem czasu wolnego seniorów w kontekście teorii aktywności}

Aktywność osób starszych w dużej mierze wiąże się z ich czasem wolnym. Pojęcie to jest $\mathrm{w}$ różnoraki sposób określane w literaturze naukowej. Bogusław Milerski i Bogusław Śliwerski podają, że czas wolny stanowi jedno z zasadniczych pojęć w pedagogice społecznej, które określa „zakres i jakość spożytkowania przez człowieka czasu, jaki ma on do wyłącznej dyspozycji; jest to zatem czas, jaki pozostaje osobie do swobodnej decyzji po wykonaniu przez nią czynności czy zadań koniecznych i obowiązkowych" (Milerski, Śliwerski 2000: 38). Czas wolny może być przeznaczony na odpoczynek (fizyczny lub psychiczny), rozrywkę, działalność społeczną, rozwój własnych zainteresowań, pasji czy uzdolnień, a także samowychowanie i samokształcenie (Milerski, Śliwerski 2000: 38).

Analiza wyżej przytoczonej definicji pozwala wyodrębnić dwa główne aspekty czasu wolnego: ilościowy i jakościowy (Orłowska 2007: 52). Pierwszy z nich odnosi się do rozmiarów czasu wolnego, jakim dysponuje jednostka (czas wolny stanowi określoną część ogólnego budżetu czasu'), z kolei drugi dotyczy podejmowanych w czasie wolnym czynności (form wykorzystania czasu wolnego²), które określane są m.in. jako wypoczynek czy rekreacja (Zawadzka, Ferenz 1998: 9-10). Definicja ta wskazuje również na czynności (bądź zadania), które nie zaliczają się do obszaru czasu wolnego (czynności konieczne i obowiązkowe ${ }^{3}$ ).

Aktywność podejmowaną w czasie wolnym (wypoczynek) charakteryzują trzy podstawowe cechy: dobrowolność (nie może mieć ona charakteru obowiązkowego), niezarobkowość (nie może być

1 Budżetem czasu określa się „zestawienie odcinków czasu przewidzianych na realizację różnych czynności życiowych" (Pięta 2004: 18). Można mówić o dobowym i tygodniowym budżecie czasu; może być on rozpatrywany także w dłuższych przedziałach czasu (Pięta 2004: 18).

2 W literaturze przedmiotu proponuje się rozmaite klasyfikacje form spędzania czasu wolnego (zob. Pięta 2004; Napierała, Muszkieta 2011). Z uwagi „na złożoność i bogactwo treści, z trudem dają się one usystematyzować i ująć w jednolity schemat i wzorce" (Walczak 1994: 17-18).

3 Zalicza się do nich czynności, które wiążą się z zaspokajaniem potrzeb biologicznych i higienicznych oraz czynności o charakterze obowiązkowym, np. związane z nauką, pracą, życiem rodzinnym (Przecławski 1997: 75). 
zasadniczym źródłem dochodu) i przyjemność (Przecławski 1997: 75-76). Szczególnie ważna jest pierwsza z wymienionych cech, która „wskazuje na swobodny, zgodny z własnymi oczekiwaniami, potrzebami i zainteresowaniami wybór formy zachowania" (Denek 2011: 90). $\mathrm{Ma}$ to duże znaczenie $\mathrm{z}$ wychowawczego punktu widzenia, zachowania wolnoczasowe stanowią bowiem często przejaw rzeczywistych dążeń bądź postaw jednostki (Przecławski 1997: 76). Jak zaznacza Ryszard Winiarski: „Klasyfikując czynności, które zaliczamy do rekreacji, musimy pamiętać, że nie forma, lecz podmiotowa ocena decyduje o ich rekreacyjnym charakterze. Ta sama czynność może być bowiem wykonywana dobrowolnie i stanowić formę rekreacji, a innym razem obowiązkowo i być traktowana jako praca" (Winiarski 2011: 16). Istotne jest więc to, jakie znaczenie nadaje człowiek podejmowanym rodzajom (formom) aktywności w określonym momencie (momentach) swojego życia.

Czas wolny może spełniać różne funkcje w życiu jednostki, np. kształcącą, opiekuńczą, integracyjną, środowiskową (Denek 2011: 103-105). Kamiński sprowadza je do trzech zasadniczych: odpoczynku, zabawy i pracy nad sobą (Kamiński 1974: 353-354). Odpoczynek oznacza „odreagowywanie fizycznego zmęczenia i psychicznego znużenia w spokoju, ciszy, w kontemplacji” (Kamiński 1974: 353). Zabawa to przeciwieństwo biernego wypoczynku, „wyraża potrzebę ruchu, nowości, przygody, hazardu, zmienności wrażeń, iluzji. Stanowi odreagowywanie nudy i monotonii [...]. Może się wyrażać w czynnościach realnych (np. wycieczka) lub w przeżywaniu fikcji (np. film)” (Kamiński 1974: 353). Natomiast praca nad sobą wyraża „potrzebę samorozwoju w różnych postaciach samokształcenia (nie tylko intelektualnego)” (Kamiński 1974: 353). Oznacza ona „dobrowolne i samodzielne nabywanie w czasie wolnym wiadomości i umiejętności w celu samodoskonalenia, tj. wszechstronnego rozwoju [...] osobowości" (Pięta 2004: 52). Z wychowawczego punktu widzenia ważne jest zachowanie właściwej równowagi pomiędzy poszczególnymi funkcjami czasu wolnego. Żadna $z$ wymienionych funkcji nie powinna dominować przez dłuższy czas w życiu jednostki (Orłowska 2007: 64).

Znaczne zmiany budżetu czasu po przejściu człowieka na emeryturę można zaobserwować, jeśli weźmie się pod uwagę ogólny podział zajęć (w ciągu doby) na: pracę zawodową, dodatkową pracę 
zarobkową, dojazdy do pracy, zaspokajanie podstawowych potrzeb organizmu, obowiązki domowe, obowiązkowe kształcenie się oraz aktywność podejmowaną w czasie wolnym. Po zastosowaniu tej klasyfikacji do sytuacji ludzi w wieku senioralnym, budżet czasu przedstawia się zwykle w następujący sposób: czas poświęcony na zaspokajanie podstawowych potrzeb organizmu, czas przeznaczony na obowiązki domowo-rodzinne oraz czas wolny (Małecka 1985: 95-96). Czas wolny stanowi więc istotny składnik w całościowym budżecie czasu seniorów (Tokaj 2000: 105).

Aktywność wolnoczasowa to ważny element życia człowieka w różnych jego fazach. Jak podaje Lucjan Turos, od sposobu wykorzystania czasu wolnego zależy m.in. stan zdrowia jednostki, jej samopoczucie, rozwój w rozmaitych dziedzinach, umiejętność przystosowywania się do zmieniających się warunków, np. społecznych, kulturowych, ekonomicznych (Turos 1999: 357-358). Rola użytkownika czasu wolnego należy do najistotniejszych ról społecznych ludzi w starszym wieku (Szatur-Jaworska 2006b: 56). Na podstawie wyników przeprowadzonych badań Małgorzata Halicka i Jerzy Halicki wyodrębnili pięć typów aktywności, jakie podejmowane są przez osoby starsze w czasie wolnym. Zalicza się do nich: aktywność rekreacyjno-hobbistyczna (np. spacery, prace na działce, zajęcia „miłośnicze”), aktywność receptywna (np. oglądanie programów telewizyjnych, czytanie gazet, książek), aktywność zorientowana publicznie (np. działalność społeczna, polityczna), aktywność integracyjna (np. spotkania ze znajomymi, spotkania w klubie seniora), inne rodzaje aktywności (formy aktywności, które nie mieszczą się w obrębie wyżej wymienionych typów) (Halicka, Halicki 2002: 207). Wyniki badań zrealizowanych przez Halicką i Halickiego (Halicka, Halicki 2002: 205), a także rezultaty niektórych badań i analiz przeprowadzonych w kolejnych latach (zob. Skibińska 2006; Woszczyk 2009; Brzezińska 2011; Banach 2013; Zwoliński 2017), wskazują na dominację biernych form wypoczynku wśród polskich seniorów.

Tymczasem, zgodnie z założeniami teorii aktywności, człowiek starszy - dzięki aktywnemu stylowi życia - „czuje się potrzebny, spełniony, odczuwa satysfakcję i planuje dalsze działania” (Wawrzyniak 2017b: 28). Zachowanie aktywności w wieku senioralnym umożliwia człowiekowi nie tylko utrzymanie dobrego stanu zdrowia, sprawności, ale jest także ważnym czynnikiem pobudzającym do przejęcia 
odpowiedzialności za własne życie (Halicka, Kramkowska 2011: 42). Aktywność osoby starszej może zależeć jednak od różnych czynników. W przypadku aktywności wolnoczasowej za szczególnie istotne należy uznać czynniki: biologiczne (np. stan zdrowia), społeczno-demograficzne (np. płeć), gospodarczo-ekonomiczne (np. sytuacja materialna), psychiczne (np. cechy osobowości) (Winiarski 1989: 85-86) oraz kulturowe (np. tradycje) (Berbeka, Makówka, Niemczyk 2008: 25). Wyróżnione grupy czynników z pewnością nie uwzględniają wszystkich możliwości. Sposób wykorzystania czasu wolnego przez ludzi starszych zależy również m.in. od tego, czy mieszkają oni samotnie, z rodziną (partnerem) czy też korzystają z oferty placówek opiekuńczych (Zwoliński 2017: 287). Wiele w tym zakresie zależy także od dotychczasowych doświadczeń seniorów (Kurek 2008: 300). W obliczu rozmaitych barier aktywności osób w wieku senioralnym, szczególnego znaczenia nabiera problem aktywizacji ludzi starszych. Skoro bowiem aktywność odgrywa tak ważną rolę w życiu człowieka starego, należy podejmować działania zachęcające do aktywności i/lub ułatwiające prowadzenie aktywnego życia.

Aktywizacja to „wzmaganie, także wzmaganie się aktywności, uaktywnianie (się)" (Górnikowska-Zwolak 1999: 9). W przypadku seniorów aktywizacja stanowi „proces stwarzania możliwości i warunków osobom starszym do tego, aby mogły realizować szeroko pojmowaną aktywność. Ma ona związek z zagadnieniem społecznej inkluzji” (Kapralska 2015: 246). Aktywizacja łączy się z przekonaniem, że aktywność określonej grupy jest niewystarczająca i wymaga podejmowania działań o charakterze naprawczym (Kapralska 2015: 246).

Do zasadniczych celów aktywizacji ludzi starszych zalicza się w szczególności: zachowanie sprawności fizycznej oraz dobrego stanu zdrowia; usamodzielnienie osoby starszej; wdrażanie do współdziałania $\mathrm{z}$ innymi, współżycia $\mathrm{w}$ grupie i środowisku; umożliwianie i poszerzanie uczestnictwa w życiu społecznym; utrzymywanie bądź pobudzanie wiary w sens życia; pobudzanie twórczego działania; rozwijanie zainteresowań (Kozaczuk 1995: 25-26; Kurtyka-Chałas 2014: 26; Chabior 2017b: 65). Aktywizacja może dotyczyć różnych sfer funkcjonowania seniorów, np. fizycznej, społecznej, intelektualnej (zob. Ziomek-Michalak 2014; Różański 2017). Może być realizowana w rozmaitych „formach, a ich dobór zależy w głównej mierze od indywidualnych cech człowieka, takich jak: wiek, wykształcenie, 
miejsce zamieszkania, zainteresowania, stan psychiczny, zdrowie fizyczne, oraz od czynników zewnętrznych: programów aktywizacji, możliwości organizacyjnych i materialnych osób, instytucji i środowisk podejmujących te działania" (Chabior 2017b: 65).

$\mathrm{W}$ procesie aktywizacji istotne jest uwzględnienie indywidualnych cech każdego człowieka, takich jak np. wiek, samopoczucie czy cechy osobowości (Gościniewicz, Szkurłat 2015: 470). Agata Chabior wymienia $\mathrm{w}$ tym zakresie również $\mathrm{m}$.in.: wiedzę pragmatyczną (w przypadku seniorów to zdobywane przez lata doświadczenia życiowe), kompetencje zawodowe i społeczne oraz pasje i zainteresowania (Chabior 2017a: 70); te ostatnie są szczególnie istotne z punktu widzenia aktywizacji wolnoczasowej. Ważne jest również właściwe rozpoznanie potrzeb ludzi starszych, ich dążeń, pragnień, a także doświadczanych przez nich trudności.

Aktywizacja nie może być kojarzona ze zmuszaniem osób starszych do aktywności (uaktywnianiem na siłę) (Leszczyńska-Rejchert 2016: 94) czy też narzucaniem rozmaitych jej form. Jak podaje Anna Leszczyńska-Rejchert: „Należy uszanować preferencje najstarszej generacji, stworzyć warunki wyboru i umożliwiać podjęcie samodzielnych decyzji w tym względzie" (Leszczyńska-Rejchert 2016: 95). Ma to szczególne znaczenie w przypadku aktywności wolnoczasowej, a więc tej, którą cechuje dobrowolność i która jest źródłem przyjemności, a nierzadko też satysfakcji. W dużej mierze „o podmiotowym wymiarze czasu wolnego świadczy doświadczanie przez osobę poczucia podmiotowości w danym interwale czasu, czyli poczucie własnej mocy sprawczej w zakresie sposobów gospodarowania czasem (sprawstwo), wypełniania go wysoko wartościowanymi treściami i formami (realizacja własnych preferencji) oraz ponoszenie odpowiedzialności za podejmowane działania i ich konsekwencje” (Czerepaniak-Walczak 2007: 224).

Aktywizacja (również wolnoczasowa) powinna być zatem ukierunkowana przede wszystkim na usamodzielnianie osób starszych oraz wzbudzanie ich gotowości do podejmowania działań na rzecz siebie i innych ludzi (Chabior 2017b: 65). W procesie aktywizacji każdy człowiek winien być traktowany indywidualnie i podmiotowo (Kozaczuk 1995: 26). 


\section{Uwagi końcowe}

$\mathrm{Z}$ punktu widzenia współczesnej pedagogiki istotnym problemem jest zarówno kwestia wycofywania się osób starszych $\mathrm{z}$ aktywnego życia, jak i zachowania aktywności w okresie późnej dorosłości. Szczególnie ważne wydaje się to, czy i w jakim stopniu aktywność seniorów można stymulować. Dla pedagogów teoria aktywności, która zakłada, że „warunkiem pomyślnej adaptacji do starości jest utrzymywanie na dotychczasowym poziomie aktywności lub zastępowanie jej form z poprzednich okresów [życia - przyp. aut.] nowymi" (Orzechowska 2007: 176), stanowi punkt wyjścia do poszukiwania sposobów aktywizacji ludzi w starszym wieku (Dzięgielewska 2006: 163-164).

Jak już zauważono, aktywność osób starszych ściśle wiąże się z ich czasem wolnym, który spełnia wiele istotnych funkcji w ich życiu. Podejmowana w czasie wolnym aktywność może służyć bowiem nie tylko odpoczynkowi, zabawie czy integracji społecznej, ale także pracy nad sobą. Czas wolny - zwłaszcza z perspektywy pedagogicznej - powinien być rozpatrywany z jednej strony jako przestrzeń do rozwoju i samorealizacji człowieka, z drugiej - jako źródło różnorakich zagrożeń (Nowocień 2019: 31). Dla osób starszych może być on przestrzenią dla rozwijania rozmaitych pasji, poszukiwania nowych zajęć, ale niekiedy też bezczynności (Zrałek 2014: 34), np. z uwagi na problemy zdrowotne, trudności finansowe, sytuację rodzinną czy brak określonych umiejętności, zainteresowań lub chęci do podejmowania aktywności. Stąd problematyka czasu wolnego seniorów powinna budzić zainteresowanie badaczy, w tym przedstawicieli nauk o wychowaniu, a także praktyków edukacji. Szczególnie istotne wydaje się poszukiwanie rozwiązań, które sprzyjałyby aktywizacji wolnoczasowej ludzi starszych oraz rozwijaniu ich umiejętności do podnoszenia jakości życia w obszarze czasu wolnego (Toczek-Werner, Marak, Wyrzykowski 2018: 128). Odpowiada to ściśle celom działalności pedagogów społecznych. Jak stwierdza bowiem Astrid Tokaj:

Wszelkie działania podejmowane na gruncie pedagogiki społecznej w sferze teoretycznej, badawczej czy wreszcie praktycznej wobec ostatniej fazy życia człowieka są (czy też winny być) podporządkowane w szczególności osiągnięciu jednego zasadniczego celu, jakim jest podniesienie jakości życia seniorów w starości doświadczanej w wymiarze zarówno 
indywidualnym, jak i społecznym. A zatem, głównym zadaniem pedagogiki społecznej w tym kontekście jest tworzenie jak najbardziej optymalnych warunków egzystencjalnych i rozwojowych - dostosowanych do faktycznych możliwości funkcjonalno-fizycznych, psychospołecznych i ekonomicznych ludzi starych. [...] Z realizacją owego zadania nierozerwalnie wiąże się podnoszenie kompetencji życiowych ludzi starszych (Tokaj 2008: 230-231).

\section{Bibliografia}

Banach M. (2013). Czas wolny osób starszych, [w:] J. Matejek, E. Zdebska (red.), Senior w rodzinie i instytucji spotecznej, Kraków: Iris Studio, s. 97-107.

Berbeka J., Makówka M., Niemczyk A. (2008). Podstawy ekonomiki $i$ organizacji czasu wolnego, Kraków: Wydawnictwo Uniwersytetu Ekonomicznego.

Błachnio A. (2019). Potencjat osób w starości. Poczucie jakości życia w procesie starzenia sie, Bydgoszcz: Wydawnictwo Uniwersytetu Kazimierza Wielkiego.

Brzezińska M. (2011). Proaktywna starość. Strategie radzenia sobie ze stresem w okresie późnej dorostości, Warszawa: Difin SA.

Chabior A. (2011). Aktywizacja i aktywnośc ludzi w okresie późnej dorostości, Kielce: Wydawnictwo Wszechnicy Świętokrzyskiej.

Chabior A. (2017a). Aktywizacja i aktywność w okresie póznej dorostości, [w:] Encyklopedia starości, starzenia się i niepetnosprawności, red. A.A. Zych, t. 1, Katowice: Stowarzyszenie Thesaurus Silesiae - Skarb Śląski, s. 65-71.

Chabior A. (2017b). Wspomaganie procesu pomyślnego starzenia się u ludzi starych. Między powinnościq a profesja, Kraków: Oficyna Wydawnicza "Impuls".

Czerepaniak-Walczak M. (2007). Od próżniaczenia do zniewolenia - w poszukiwaniu dyskursów czasu wolnego, [w:] E. Marynowicz-Hetka (red.), Pedagogika spoteczna. Podręcznik akademicki 2. Debata, Warszawa: Wydawnictwo Naukowe PWN, s. 219-235.

Denek K. (2011). Edukacja pozalekcyjna i pozaszkolna, Poznań: Wydawnictwo Naukowe Wyższej Szkoły Pedagogiki i Administracji.

Dzięgielewska M. (2006). Aktywność spoteczna i edukacyjna na tle innych typów aktywności, [w:] B. Szatur-Jaworska, P. Błędowski, M. Dzięgielewska, Podstawy gerontologii spotecznej, Warszawa: Oficyna Wydawnicza ASPRA-JR, s. 161-165.

Gościniewicz M., Szkurłat J. (2015). Aktywność i aktywizacja osób starszych jako jedno z gtównych wyzwañ wspótczesności, [w:] M. Krawczyk-Blicharska,J. Szkurłat (red.),Edukacja, rynek pracy, rozwój. Obszary wsparcia 
i aktywizacji wybranych grup spotecznych, Kielce: Uniwersytet Jana Kochanowskiego, s. 463-482.

Górnikowska-Zwolak E. (1999). Aktywizacja, aktywnośc, [w:] D. Lalak, T. Pilch (red.), Elementarne pojecia pedagogiki spotecznej i pracy socjalnej, Warszawa: Wydawnictwo Akademickie „Żak”, s. 9-11.

Halicka M., Halicki J. (2002). Integracja spoteczna i aktywność ludzi starszych, [w:] B. Synak (red.), Polska starośc, Gdańsk: Wydawnictwo Uniwersytetu Gdańskiego, s. 189-218.

Halicka M., Kramkowska E. (2011). Aktywność osób starszych i przyktady samoorganizowania się seniorów w Polsce, „Trzeci Sektor”, nr 25, s. 36-43.

Halicki J. (2006). Spoteczne teorie starzenia sie, [w:] M. Halicka, J. Halicki (red.), Zostawić ślad na ziemi. Ksiegga pamiątkowa dedykowana Profesorowi Wojciechowi Pędichowi w 80 rocznice urodzin i 55 rocznice pracy naukowej, Białystok: Wydawnictwo Uniwersytetu w Białymstoku, s. 255-276.

Kaczmarczyk M., Trafiałek E. (2007). Aktywizacja osób w starszym wieku jako szansa na pomyślne starzenie, „Gerontologia Polska”, t. 15, nr 4, s. $116-118$.

Kamiński A. (1974). Funkcje pedagogiki spotecznej. Praca socjalna i kulturalna, Warszawa: PWN.

Kamiński A. (1986). Aktywnośc jako wzmaganie żywotności osób starszych, [w:] Encyklopedia seniora, red. F.W. Sawicka, B. Maryanska, E. Stańczuk, Warszawa: Wiedza Powszechna, s. 115-117.

Kapralska E. (2015). Aktywizacja seniorów jako problem spoteczny, [w:] M. Synowiec-Piłat, B. Kwiatkowska, K. Borysławski (red.), Inkluzja czy ekskluzja? Człowiek stary w spoteczenstwie, Wrocław: Wrocławskie Towarzystwo Naukowe, s. 241-255.

Kozaczuk L. (1995). Terapia zajecciowa w domach pomocy spotecznej, Warszawa: Wydawnictwo Interart.

Kurek E. (2008). Czas wolny. Refleksje gerontologiczne, [w:] R. Konieczna-Woźniak (red.), Dorostość wobec starości. Oczekiwania - Radości-Dylematy, Poznań: Wydawnictwo Naukowe UAM, s. 295-304.

Kurtyka-Chałas J. (2014). Starość i jej oblicza. Wybrane psychologiczne aspekty funkcjonowania osób starszych, Lublin: Towarzystwo Wydawnictw Naukowych Libropolis.

Leszczyńska-Rejchert A. (2016). Praca socjalna z seniorami w perspektywie geragogiki, Olsztyn: Wydawnictwo Uniwersytetu Warmińsko-Mazurskiego.

Małecka B.Z.(1985). Elementy gerontologii dla pedagogów, Gdańsk: Wydawnictwo Uniwersytetu Gdańskiego.

Milerski B., Śliwerski B. (red.). (2000). Pedagogika. Leksykon PWN, Warszawa: Wydawnictwo Naukowe PWN.

Miszczak E. (2010). Aktywność seniorów sposobem przeciwdziatania negatywnym skutkom procesu starzenia sie, [w:] D. Kałuża, P. Szukalski (red.), Jakośc życia seniorów w XXI wieku. Ku aktywności, Łódź: Wydawnictwo Biblioteka, s. 24-33. 
Napierała M., Muszkieta R. (2011). Wstęp do teorii rekreacji, Bydgoszcz: Wydawnictwo Uniwersytetu Kazimierza Wielkiego.

Nowocień J. (2019). Czas pracy a czas wolny jako wartośc edukacyjna, [w:] A. Karpińska, A. Szwarc, W. Wróblewska (red.), Edukacja catożyciowa-wybrane obszary, Toruń: Wydawnictwo Adam Marszałek, s. 19-33.

Orłowska M. (2007). Przymus bezczynności. Studium pedagogiczno-spoteczne czasu wolnego bezrobotnych, Warszawa: Wydawnictwo Naukowe PWN.

Orzechowska G. (2007). Aktywność osób starszych jako kategoria uniwersal$n a$, [w:] E. Dubas (red.), Uniwersalne problemy andragogiki i gerontologii, Łódź: Wydawnictwo Uniwersytetu Łódzkiego, s. 175-183.

Pędich W. (2002). Starość, [w:] Encyklopedia zdrowia, red. W.S. Gumułka, W. Rewerski, Warszawa: Wydawnictwo Naukowe PWN, s. 914-931.

Pięta J. (2004). Pedagogika czasu wolnego, Warszawa: Zakład Wydawniczy DrukTur.

Pikuła N. (2011). Etos starości w aspekcie spotecznym. Gerontologia dla pracowników socjalnych, Kraków: Wyższa Szkoła Filozoficzno-Pedagogiczna „Ignatianum”; Wydawnictwo WAM.

Pikuła N. (2013). Senior w przestrzeni spotecznej, Warszawa: Wydawnictwo Borgis.

Przecławski K. (1997). Czas wolny dzieci i mtodzieży, [w:] Encyklopedia Pedagogiczna, red. W. Pomykało, Warszawa: Fundacja Innowacja, s. 75-77.

Różański T. (2016). Wybrane problemy czasu wolnego ludzi starszych w Polsce, [w:] M. Halicka, J. Halicki, E. Kramkowska (red.), Starość - poznać, przeżyé, zrozumieć, Białystok: Wydawnictwo Uniwersytetu w Białymstoku, s. 389-400.

Różański T. (2017). Wybrane obszary aktywizacji osób starszych w środowisku lokalnym, [w:] A. Szczurek-Boruta, K. Jas (red.), Cztowiek wykluczony $i$ cztowiek w sytuacji zagrożenia wykluczeniem spotecznym, edukacyjnym, kulturowym. Wyzwania, powinności pedagogiki, zadania, Toruń: Wydawnictwo Adam Marszałek, s. 185-201.

Skibińska E.M. (2006). Mikroświaty kobiet. Relacje autobiograficzne, Warszawa: Uniwersytet Warszawski.

Steuden S. (2011). Psychologia starzenia się i starości, Warszawa: Wydawnictwo Naukowe PWN.

Synak B. (1987). Mtodzi emeryci, Warszawa: Instytut Wydawniczy Związków Zawodowych.

Szarota Z. (2004). Gerontologia spoteczna i oświatowa. Zarys problematyki, Kraków: Wydawnictwo Naukowe Akademii Pedagogicznej.

Szarota Z. (2010). Starzenie się i starość w wymiarze instytucjonalnego wsparcia na przykładzie Krakowa, Kraków: Wydawnictwo Uniwersytetu Pedagogicznego.

Szatur-Jaworska B. (2006a). Cechy gerontologii spotecznej jako dyscypliny naukowej, [w:] B. Szatur-Jaworska, P. Błędowski, M. Dzięgielewska, Podstawy gerontologii spotecznej, Warszawa: Oficyna Wydawnicza ASPRA-JR, s. 16-25. 
Szatur-Jaworska B. (2006b). Starość - opis fazy, [w:] B. Szatur-Jaworska, P. Błędowski, M. Dzięgielewska, Podstawy gerontologii spotecznej, Warszawa: Oficyna Wydawnicza ASPRA-JR, s. 45-58.

Toczek-Werner S., Marak J., Wyrzykowski J. (2018). Czas wolny wroctawskich seniorów i jego wykorzystanie na turystykę i rekreacje ruchowa, Wrocław: Wyższa Szkoła Handlowa.

Tokaj A. (2000). U progu starości (Studium socjopedagogiczne), Poznań: Eruditus.

Tokaj A. (2008). Starośc w pedagogice spotecznej, „Studia Edukacyjne”, nr 7, s. 221-232.

Trafiałek E. (2006). Starzenie się i starość. Wybór tekstów z gerontologii spotecznej, Kielce: Wszechnica Świętokrzyska.

Trafiałek E. (2013). Starość w Polsce, [w:] T. Pilch, T. Sosnowski (red.), Zagrożenia człowieka $i$ idei sprawiedliwości spotecznej, t. 1, Warszawa: Wydawnictwo Akademickie „Żak”, s. 187-201.

Turos L. (1999). Andragogika ogólna, Warszawa: Wydawnictwo Akademickie „Źak”.

Walczak M. (1994). Wychowanie do wolnego czasu, Zielona Góra: Wyższa Szkoła Pedagogiczna.

Wawrzyniak J.K. (2017a). Starzenie się i jego charakterystyka, [w:] A. Fabiś, J.K. Wawrzyniak, A. Chabior, Ludzka starość. Wybrane zagadnienia gerontologii spotecznej, Kraków: Oficyna Wydawnicza „Impuls”, s. 42-78.

Wawrzyniak J.K. (2017b). Teorie starzenia się $i$ przystosowania do starości, [w:] A. Fabiś, J.K. Wawrzyniak, A. Chabior, Ludzka starośc. Wybrane zagadnienia gerontologii spotecznej, Kraków: Oficyna Wydawnicza „Impuls”, s. 26-42.

Winiarski R. (1989). Wstęp do teorii rekreacji (ze szczególnym uwzględnieniem rekreacji fizycznej), Kraków: Akademia Wychowania Fizycznego.

Winiarski R. (2011). Wprowadzenie do zagadnień rekreacji i czasu wolnego, [w:] R. Winiarski (red.), Rekreacja i czas wolny. Studia humanistyczne, Warszawa: Oficyna Wydawnicza Łośgraf, s. 13-28.

Woszczyk P. (2009). Style życia ludzi starych, czyli co robić z czasem wolnym na emeryturze, [w:] W. Muszyński (red.), „Mate tęsknoty?”. Style życia w czasie wolnym we wspótczesnym spoteczeństwie, Toruń: Wydawnictwo Adam Marszałek, s. 126-139.

Zawadzka A., Ferenz K. (1998). Spoteczne aspekty wypoczynku mtodych kobiet, Wrocław: Wydawnictwo Uniwersytetu Wrocławskiego.

Ziomek-Michalak K. (2014). Wykorzystanie potencjatu środowiska lokalnego w pracy z osobami starszymi, [w:] M. Mikołajczyk (red.), Pomoc spoteczna i praca socjalna - różne oblicza i zadania, Warszawa: Wydawnictwo Akademii Pedagogiki Specjalnej, s. 70-83.

Zrałek M. (2014). Spoteczne konteksty starzenia się w Polsce, [w:] A. Fabiś, M. Muszyński, Ł. Tomczyk, M. Zrałek, Starośc w Polsce. Aspekty spoteczne i edukacyjne, Oświęcim: Wydawnictwo Państwowej Wyższej Szkoły Zawodowej, s. 9-50. 
Zwoliński A. (2017). Czas wolny ludzi starszych, [w:] Encyklopedia starości, starzenia się i niepetnosprawności, red. A.A. Zych, t. 1, Katowice: Stowarzyszenie Thesaurus Silesiae - Skarb Śląski, s. 287-290.

\section{ADRES DO KORESPONDENCJI}

Dr Tomasz Różański

Uniwersytet Mikołaja Kopernika w Toruniu

Wydział Filozofii i Nauk Społecznych

Instytut Nauk Pedagogicznych

Katedra Pedagogiki Społecznej i Pracy Socjalnej

e-mail: tomrozan $1 @ u m k . p l$ 